DOI: $10.17951 / \operatorname{lrp} .2019 .38 .4 .25-40$

\author{
Bernadeta Szczupat \\ Akademia Pedagogiki Specjalnej im. M. Grzegorzewskiej \\ ORCID - 0000-0002-2127-417X \\ JOLANTA IZABELA WiŚNIEWSKA \\ Akademia Pedagogiki Specjalnej im. M. Grzegorzewskiej \\ ORCID - 0000-0002-7792-1014
}

\title{
SAMOTNOŚĆ I POCZUCIE OSAMOTNIENIA W NARRACJI OSÓB W WIEKU PÓŹNEJ STAROŚĆI - PRZEJAWY ORAZ MOŻLIWOŚCI PRZECIWDZIAŁANIA
}

\begin{abstract}
Streszczenie: Proces starzenia się jest nieuniknionym zjawiskiem życiowym zarówno pod względem indywidualnym, jak i społecznym. Osoby starsze narażone są na pojawienie się poczucia samotności i osamotnienia. Samotność utożsamiana jest z brakiem relacji międzyludzkich lub ze znacznym ich ograniczeniem. Samotność prawie zawsze prowadzi do marginalizacji lub wykluczenia osób starszych, które jej doświadczają. W artykule przedstawiono wyniki badań jakościowych dotyczących samotności i poczucia osamotnienia w narracji osób w wieku późnej starości.
\end{abstract}

Słowa kluczowe: samotność, osoby starsze, osoby w wieku późnej starości, wsparcie społeczne

\section{WPROWADZENIE}

Starzenie się jest wieloaspektowym procesem, obejmującym zmiany fizyczne i psychiczne. Proces starzenia u każdego człowieka ma specyficzny charakter, ponieważ indywidualne jest zarówno tempo, jak i nasilenie tego zjawiska. Kondycja osób w podeszłym wieku zależy głownie od istniejących chorób przewlekłych oraz od procesu fizjologicznego starzenia się. Pogorszenie sprawności umysłowej, wyrażone trudnościami z koncentracją uwagi i zapamiętywaniem oraz utrata pełnionych dotychczas ról społecznych są często przyczyną obniżonej samooce- 
ny, a nawet izolacji i samotności. Jednym z największych problemów, jaki może dotknąć starszego człowieka jest życie w samotności, bez rodziny, przyjaciół, znajomych. Samotność rozumiana jest nie tylko jako izolacja od innych lub życie w obcym środowisku, którego nie można już zmienić, ale także jako poczucie obcości, odtrącenia przez otoczenie. Doświadczanie samotności może prowadzić do marginalizacji lub wykluczenia z życia społecznego. Przyczyny powstawania tego zjawiska są różnorodne. Osoby takie nie utrzymują kontaktów ze swoim bliższym lub dalszym otoczeniem z powodu świadomego wyboru lub z powodu braku takiej możliwości (Posłuszna 2012, s. 76-78; Stochmiałek 2012, s. 93-100; Ziomek-Michalak 2015, s. 175-180). Należy jednak zaznaczyć, że jednym z kluczowych czynników zapobiegania samotności i pomyślnego starzenia się jest podtrzymywanie więzi z innymi ludźmi i aktywność społeczna.

Samotność ze względu na wielorakie przyczyny i różnorodny wymiar jest złożonym zagadnieniem. Zwykle terminy „samotność” i „osamotnienie” są stosowane jako synonimy, bez wyraźnego zaznaczania różnic między nimi, a głównie charakteryzowane jako zjawiska o negatywnych konsekwencjach. Jednak można traktować samotność jako obiektywny stan fizyczny, objawiający się brakiem kontaktów z innymi, wskutek odrzucenia lub odosobnienia, realizowany przymusowo (wynikający z sytuacji życiowej) bądź dobrowolnie. Ten stan może się wiązać z subiektywnym poczuciem osamotnienia, choć nie musi być jego warunkiem, gdyż jednostka może doświadczać osamotnienia mimo fizycznej obecności innych ludzi. Samotność może być przeżywana pozytywnie bądź negatywnie lub zmiennie, zależnie od różnych uwarunkowań, co ukazuje jej względność i labilność natężeń (Dubas 2000, s. 111-114).

Samotność wpisuje się w kondycję psychiczną człowieka. W gerontologii istnieje wyraźny podział na osamotnienie oraz samotność. Samotność rozumiana jest jako długie pozostawanie w odosobnieniu, brak uczestnictwa w życiu społecznym, złe wykreowanie roli społecznej, niemożność fizycznego kontaktu ze społeczeństwem. Natomiast osamotnienie skupia się na psychologicznej stronie samotności, uczuciu wyobcowania mimo istnienia fizycznych możliwości kontaktu z drugim człowiekiem. Można wyróżnić samotność spowodowaną niejako fizycznym brakiem ludzi, ale także samotność wśród ludzi (Szukalski 2005, s. 217-221; Drageset, Eide, Furnes i in. 2015, s. 1529-1534).

Osoby starsze narażone są na pojawienie się poczucia samotności i osamotnienia. Uważa się, że człowiek dorosły jest w stanie poradzić sobie z trudnymi sytuacjami, zwłaszcza jeśli okoliczności stwarzają taką szansę. Osoba w wieku podeszłym ma mniejsze możliwości w tym zakresie, ponieważ musi zmagać się ze skutkami biologicznego i psychicznego starzenia się. Ponadto zmiany regresyjne powodują ograniczenie zdolności adaptacyjnych, utratę sprawności funkcjonalnej 
oraz spadek energii i odporności. Czynniki te predysponują do przyjmowania biernego stylu życia. Osoba starsza musi posiadać dużą wolę do zachowania aktywności i radzenia z trudnymi sytuacjami (Szczupał 2018, s. 16-19; Wiśniewska 2018, s. 28-30).

Badania (Christiansen, Larsen, Lasgaard 2016, s. 80-85) wykazały istotną statystycznie korelację między poczuciem samotności a występowaniem chorób serca i migreny zarówno u mężczyzn, jak i u kobiet. Natomiast związek cukrzycy z samotnością okazał się charakterystyczny tylko dla płci żeńskiej. Dowiedziono również, że brak aktywności społecznej i problemy ze snem mogą być czynnikiem predysponującym do wyższych wskaźników poczucia osamotnienia w starszym wieku.

Samotność może być również definiowana jako samotne zamieszkiwanie. Piotr Szukalski (2005, s. 217-218) jednoznacznie stwierdza, że nadrzędnym czynnikiem zwalczającym samotność jest wspólne zamieszkiwanie z bliskimi osobami, które są w stanie otoczyć osoby starsze troskliwą i godną opieką. Człowiek potrzebuje w swoim życiu obecności innych ludzi nie tylko w trudnych sytuacjach i momentach bezradności. Bliskość drugiej osoby jest potrzebna dla utrzymania harmonii w aspekcie psychofizycznym. Okres starości jest sumą powstających zmian w każdej sferze życia. Konieczność adaptacji do tych zmian może być stresogenna, ale także stanowić źródło satysfakcji (Heitzman 2018, s. 24-30; Świtoń, Wnuk 2015, s. 244-246).

Okres starości uznawany jest jako umiejętność dokonania wyboru pomiędzy tym, z czego należy stopniowo rezygnować a tym, w czym nadal aktywnie uczestniczyć. Adaptacja do starości to sztuka radzenia z problemami, które przynosi codzienność, dostrzeganie dobrych stron tego procesu, a także doświadczanie zadowolenia z życia.

\section{UZASADNIENIE STANOWISKA BADAWCZEGO}

Prezentowane w artykule wyniki badań jakościowych zostały zrealizowane w latach 2017-2019. Celem było poznanie opinii osób starszych na temat poczucia samotności oraz możliwości ich codziennego wsparcia. Planowano uzyskać odpowiedź na pytania: jak badani doświadczają samotności oraz poczucia osamotnienia oraz z jakich możliwości wsparcia korzystają osoby w wieku późnej starości?

W ramach badań przeprowadzono siedem wywiadów - z sześcioma kobietami i jednym mężczyzną. Były to obszerne wypowiedzi dotyczące subiektywnych doświadczeń i przeżyć badanych osób. Próby dotarcia do subiektywnych doświadczeń 
wymagają od badacza i badanych wchodzenia w głąb zjawisk oraz poznawania ich w całej złożoności (Pilch, Bauman 2010, s. 65-69). Badania były przeprowadzone $\mathrm{w}$ domach rodzinnych badanych w województwie dolnośląskim i mazowieckim. Podstawowym wyznacznikiem doboru badanych był wiek (75-85 lat), ich funkcjonowanie psychofizyczne, samodzielne zamieszkanie w domu rodzinnym, brak (lub sporadyczny) kontakt z rodziną oraz uczestnictwo w zajęciach Dziennego Domu Pomocy Społecznej (DDPS). Każdy z wywiadów miał taki sam układ na podstawie założeń metodologii wywiadu narracyjnego (Kos 2013, s. 91-112). W obrębie wywiadu narracyjnego występują jeszcze dwie jego odmiany: wywiad ekspercki oraz autobiograficzno-narracyjny. W związku z tym, że w badaniach zależało nam zarówno na ukazaniu codziennych sytuacji i zmian zachodzących w życiu badanych, jak i umiejscowieniu tych sytuacji w czasie, wykorzystano wywiad autobiograficzno-narracyjny. W tego rodzaju badaniach badany ma możliwość prześledzenia pewnych wspomnień, co skłania go do refleksji nad tym, w jaki sposób nadaje danym zjawiskom wartości i jak interpretuje rzeczywistość (Pilch, Bauman 2010, s. 45-54). Opowieść o swoim życiu jest subiektywną interpretacją tego, co doświadcza, przeżywa i doznaje badana osoba (Demetrio 2000, s. 32-41). Analizę danych narracyjnych poprzedziła transkrypcja. Teksty poszczególnych narracji zostały podzielone na części tematyczne. Dokonano ich strukturalnego opisu, który zmierzał do ustalenia procesów wynikających z narracji, m.in. określenia sytuacji narratora. Następnie określono momenty przełomowe w poszczególnych biografiach oraz wyłoniono kategorie wspólne dla większości narracji. Do takich kategorii należała samotność, poczucie osamotnienia, kontakt z rodziną, aktywność społeczna oraz otrzymywane formy wsparcia. Wywiady ukazały złożoność, różnorodność i wieloznaczność tych kategorii ${ }^{1}$.

\section{SAMOTNOŚĆ I POCZUCIE OSAMOTNIENIA W NARRACJACH BADANYCH}

Samotność jest postrzegana przez osoby badane przeważnie jako zjawisko o zabarwieniu negatywnym. Wskazuje na to wypowiedź jednej z respondentek: „Samotność w wieku starszym [...] w ogóle samotność, to jest coś strasznego" (Halina, 85 lat). Z perspektywy respondentki samotność nie powinna mieć miejsca w życiu człowieka. W idealnej, dobrej rzeczywistości, zdaniem rozmówczyni, nie byłoby osób samotnych.

${ }^{1} \mathrm{~W}$ artykule przedstawiono oryginalne wypowiedzi badanych osób starszych. Wszystkie imiona badanych osób zostały zmienione. 
Podobnie zjawisko samotności rozumie pani Barbara: „Samotność nic jest nie warta. To człowiek jest wart tyle, ile inni ludzie są koło niego” (Barbara, 83 lata). Jej zdaniem samotność jest doświadczeniem, które nic konstruktywnego nie wnosi w życie człowieka, jest bezwartościowe. Twierdzi, że wartość człowieka można rozpatrywać wyłącznie przez pryzmat bycia w społeczeństwie, stanowienia części większej całości.

Samotność, zdaniem pani Ewy, jest stanem, który wpędza człowieka w bierność: „Dla mnie samotność to jest wtedy, gdy człowiek nie potrafi działać, nawet wokół siebie, nie umie się czymś zająć” (Ewa, 85 lat). Uważa, że doświadczanie samotności doprowadza człowieka do bezczynności, bezsilności, do poczucia zagubienia i nieporadności życiowej.

Pan Zygmunt, podobnie jak pani Ewa, postrzega samotność jako stan, którego przeżywanie czyni człowieka pasywnym: „Ja należę do ludzi, którzy muszą mieć jakieś kontakty. Mnie by dobiła taka samotność” (Zygmunt, 81 lat).

Kolejnym przykładem rozumienia samotności jest łączenie jej z chorobą: „Samotność? To dosłownie kalectwo człowieka. Człowiek nie powinien być nigdy sam. To jest coś nie do zaakceptowania... I to przez nikogo. Nikomu nie życzę samotności, nikomu” (Janina, 85 lat).

Radykalny brak akceptacji dla samotności w czyimkolwiek życiu, prezentowany przez panią Janinę, nie powtarza się jednak w wypowiedziach pozostałych badanych. Niektórzy z nich twierdzą, że jest to kwestia subiektywna. Świadczą o tym słowa pani Zofii: „To jest bardzo, bardzo trudne do powiedzenia, bo każdy przeżywa tą samotność inaczej, w inny sposób” (Zofia, 85 lat). Podobnie uważa pan Zygmunt: „To zależy od charakteru człowieka, może niektórzy uciekają po prostu i chcą być samotni. No nie mogę nazwać tego chorobą, bo to jest wybór najczęściej [...] no może nie najczęściej, ale jest ta samotność z wyboru, prawda?” (Zygmunt, 81 lat). Jest to też stanowisko bliskie pani Ewie, która twierdzi: „Można być samemu, ale nie musi się być samotnym, bo to jest różnica. Można być samemu, ale to nie jest powiedziane, że jest się samotnym. Człowiek sam sobie pracuje na samotność. Zaczyna się od pewnego wieku. Jeżeli się unika otoczenia, nie mamy kontaktów z ludźmi bądź bardzo mały kontakt. Kontakt międzyludzki jest potrzebny" (Ewa, 85 lat).

W opinii rozmówców samotność jest negatywnym zjawiskiem. Doświadczanie tego stanu umniejsza wartość życia ludzkiego i wprowadza w nie chaos. Samotność wpędza człowieka w poczucie bezcelowości, bezczynności, a także bezużyteczności. Samotność kojarzy się badanym z zachwianym poczuciem sensu życia, z chorobą, z czymś, co nie pozwala człowiekowi prawidłowo funkcjonować. Ponadto zwracają uwagę na jej związek z wiekiem podeszłym. Niektórzy badani odróżniają samotność fizyczną od psychicznej. Sposób przeżywania samotności jest ich zdaniem 
indywidualny i zależy od wielu czynników. Osoba doświadczająca samotności, z przyczyn niezależnych od niej, wzbudza w badanych współczucie, samotnictwo z wyboru zaś uważają za sprzeczne z naturą człowieka, gdyż kontakty z innymi stanowią źródło zaspokajania wielu ważnych potrzeb.

Obraz człowieka samotnego przedstawia pani Maria: „Człowiek samotny to jest człowiek bardzo nieszczęśliwy. Może mieć pieniądze, może mieć dobrobyt, może mieć wszystko, ale to jest człowiek bardzo nieszczęśliwy. Lepiej żyć skromnie, a mieć towarzysza. Moje koleżanki różnie zabijają tą samotność. Jedna jeździ po świecie, bo jest bardzo bogata, ale co jej z tego bogactwa? Miłości nie kupisz" (Maria, 85 lat).

Badani seniorzy mają zróżnicowane kontakty społeczne. Pan Zygmunt mówi o nich następująco: „Brat od czasu do czasu przychodzi z małżonką swoją, także nieraz przychodzimy tu, porozmawiamy, wtedy mogę się piwa z nim napić, bo tak sam, to nie, wolę towarzystwo jakieś. Córka dwa razy w tygodniu. Syn mieszka daleko, to on rzadziej przyjeżdża - raz na półtora miesiąca, czy raz w miesiącu, to zależy" (Zygmunt, 81 lat). Respondent jest często odwiedzany przez córkę i rzadziej, ale regularnie, przez brata.

Nieco mniej systematyczne kontakty społeczne utrzymuje pani Ewa: „Nie codziennie, raz na jakiś czas [...] raz dwa tygodnie, czasami raz miesiąc. Przychodzą moje koleżanki z pracy. Znajomi, bliscy, tacy, z którymi utrzymywałam kontakt" (Ewa, 85 lat).

Inna jest sytuacja pani Zofii: „Kilka razy dziennie, bo Marysia kilka razy przychodzi, opiekunki przychodzą. A przez telefon to dwa razy w tygodniu, no to $\mathrm{z}$ rodziną, nie? A tak nie mam żadnego kontaktu, raz na pół roku, na imieniny" (Zofia, 88 lat).

Niezbyt częsty, ale regularny kontakt z bliskimi ma pani Barbara: „Z rodziną, syna, wnuków, prawnuków mam już. [...] To mam kontakty i osobiste, i telefoniczne, to zależy. Przychodzą co dwa tygodnie" (Barbara, 83 lata).

Specyficznym przypadkiem bardzo wysokiego poziomu aktywności społecznej jest pani Maria, która angażuje się w wiele działań społecznych: „Ja właściwie, szczerze mówiąc, nie mam czasu. Bo tak, przeważnie o piątej wstaję, bo tak muszę podołać wszystkim zajęciom i obowiązkom. W poniedziałek wstaję rano, bo mamy warsztaty teatralne. To żeby dojechać, ubrać się, coś zjeść, a jeszcze mamy próby, przygotować się do roli, no to do roli już wieczorem się przygotowuję. Potem jeszcze jakiś lekarz się trafi, potem idę na UTW, bo tam mam coś do załatwienia. To wszystko mi się tak nakłada, że albo tam w barze studenckim coś zjem ciepłego i do domu wracam o dziewiętnastej. We wtorek mam warsztaty dziennikarskie, też trzeba się przygotowywać, bo teraz jest rok Juliusza Słowackiego i będziemy deklamować we wrześniu jego listy do [...] najczęściej do matki. Wtorek mam 
też zajęty. A w środę, to jest tak [...] ponieważ ja też jestem edukatorem, skończyłam odpowiedni kurs, to czytam bajki dla dzieci w szkołach i przedszkolach. A w czwartek, ponieważ się zaangażowałam do wyborów do Unii Europejskiej, to mam szkolenie. Piątki też mam zajęte, rano warsztaty dziennikarskie. W sobotę mamy jeszcze spotkanie takie łączące naszą grupę, w kawiarni. A w niedzielę msza. Jestem również statystką w filmie, nieraz dostaję główne role. Potem też muszę się przygotować, bo trzydziestego pierwszego maja lecę na Rodos, na tydzień, tylko na tydzień. Lecimy we trzy koleżanki. A w lipcu jadę do Wilna. Jedziemy na sześć dni (Maria, 85 lat).

Analiza przytoczonych wypowiedzi wskazuje na związek poziomu aktywności społecznej ze stanem zdrowia. Uczestnicy badania odnosząc się do kwestii codziennych kontaktów interpersonalnych, wspominają o problemach zdrowotnych: „Tak to na co dzień chodzę do domu dziennej opieki. No a teraz siedzę w domu, bo to złamanie. I każdy z nas tam, co jakiś czas, nie przychodzi, bo chory, bo do lekarza poszedł, bo jeszcze na jakieś badania" (Jadwiga, 77 lat).

Zmniejszenie aktywności społecznej z powodu problemów zdrowotnych zauważa u siebie również pani Janina, zamieszkująca $\mathrm{w}$ domu pomocy społecznej: „Na każde święto, zawsze mamy coś. Ja nieraz nie mogę uczestniczyć ze względu na mój stan zdrowia, odczuwam nieraz duży ból głowy. Jak jestem w formie, to możemy porozmawiać. A jak źle, coś boli, to dziękuję, do widzenia, muszę się położyć" (Janina, 86 lat).

Podobnie zmniejszenie kontaktów społecznych ludzi w podeszłym wieku z powodu problemów zdrowotnych deklaruje pani Zofia: „Telefon tylko, nikt nie przychodzi, bo to za wysoko i nikt w moim wieku po schodach nie pójdzie" (Zofia, 85 lat). Jednym z najczęściej wymienianych przez osoby badane kłopotów ze zdrowiem, utrudniających kontakty z innymi ludźmi jest zredukowana możliwość poruszania się. Rozmówcy zwrócili również uwagę na choroby dotyczące narządu wzroku i słuchu: „Każdy jest na coś chory. Jedna źle słyszy, druga mniej widzi [...] i to nieraz ktoś jest jak taki wolny słuchacz" (Janina, 85lat).

$\mathrm{Na}$ bardzo różne opinie dotyczące samotności i poczucia osamotnienia składa się wiele czynników. Pani Janina uważa swoje wcześniejsze życie osobiste za nieudane. Jest przepełniona żalem do byłego męża, który zawiódł jej zaufanie. Respondentka ma wypracowane efektywne strategie radzenia sobie z samotnością, głównie poprzez zaangażowanie religijne i w społeczności osób wierzących. Jej bilans życiowy jest pozytywny: „Wszystko ma swój czas w życiu. I młodość, i życie, i radość. I to wszystko przychodzi stopniowo. Ja to znoszę ze spokojem. Bo wiem, że to następuje, miejsca trzeba ustąpić na tym świecie młodszym pokoleniom [...] i ten spokój taki jest. To zależy od człowieka. Najgorzej to zostać takim histerykiem w starości. Ja przeżywam bardzo spokojnie i przygotowuję się na drugi świat. Bo 
taka jest kolejność życia. I wszystko ma swój urok w każdym wieku. Starość też ma urok. Żyje się wspomnieniami. Nawet jak się jaki błąd popełniło w życiu [...] bo nic nie jest zawsze idealne, każdy popełnia błędy" (Janina, 85 lat).

Zupełnie inaczej przedstawia się sytuacja pani Barbary, dla której rodzina wypełniała całe jej życie, a stan utraty bliskich osób w krótkim czasie doprowadził do depresji, a nawet do podjęcia próby samobójczej: „Chciałabym, żeby rodzina była, tak jak kiedyś. Mój mąż bardzo dobry, porządny człowiek był. A potem wszystko mi się rozleciało. W jednym roku miałam pięć pogrzebów. Przeżyłam to bardzo. I zapadłam na depresję. Chciałam się otruć, gaz włączyłam. Ale potem się opamiętałam i myślę, no dobrze, ja to tam ja, ale co sąsiedzi winni, dzieci? Bo jakby wybuch był gazu [... ] i wyłączyłam wtedy" (Barbara, 83 lata).

Badane osoby przeżywają samotność w zróżnicowany sposób. Niektórzy z rozmówców odczuwają brak kontaktów społecznych pomimo przebywania w otoczeniu innych osób, co wskazuje na doświadczanie poczucia osamotnienia. Taki rodzaj samotności odczuwa pani Barbara: „Ja to chciałam do UTW chodzić, tam pomiędzy ludźmi będę trochę. Zawsze to jest inaczej, ale jak się przekonałam, to zależy, jakie to otoczenie i środowisko ludzi. Czuję się taka samotna, bo z tymi paniami nieraz się porozmawia, tam wymieni się słowa tylko, a tak to nie ma z kim, człowiek samotny [...] płakać się chce. Popłaczę, popłaczę i przestanę. I jest przerwa, i to tak mija" (Barbara, 83 lata).

Badani seniorzy doświadczają też samotności z powodu sytuacji mieszkaniowej. Próbują kompensować niedostatek kontaktów osobistych za pomocą rozmów telefonicznych, głównie z osobami w podobnym wieku i sytuacji mieszkaniowej. Taką okoliczność przedstawia między innymi pani Janina: „Przychodziła niedziela, to pani nie widziała nikogo na klatce, pustki. Ciepło, ładna pogoda, żywej duszy nie ma. Wszystko siedzi gdzieś nad wodą, po parkach. Taka sytuacja [...]. Wtedy to, telefon miałam. Bo moje towarzystwo to wszystko wiekowe, tak jak i ja. Każdy ma podobną taką sytuację, jak ja. Każda potrzebuje opieki drugiej strony. Ale te kontakty przez telefon nie wystarczały. Tyle, że się ten głos ludzki usłyszy, ale jednak czuło się tą pustkę w tym mieszkaniu, to się odczuwa. Jeszcze dwie koleżanki żyją. Jeszcze jedna $\mathrm{z}$ mężem, a druga już sama została. I też sama w czterech ścianach siedzi. Niczego nie pragnie, tylko żeby ktoś przyjechał i porozmawiał" (Janina, 85 lat).

Pani Jadwiga w swojej wypowiedzi podkreśla, że samotność wynikająca z sytuacji mieszkaniowej jest szczególnie uciążliwa w okolicznościach choroby, które uniemożliwiają lub utrudniają wyjście z domu: „Właśnie, najbardziej to teraz odczuwam samotność, jak jestem chora, to odczuwam samotność. Nie mogę nigdzie pójść - ani na zakupy, ani do domu opieki, no i ta samotność tak mnie dręczy. Jak jestem sama w mieszkaniu, to wtedy najbardziej” (Jadwiga, 77 lat). 
Samotność z powodu jednostkowego zamieszkiwania oprócz powodowania poczucia pustki przysparza również wielu obaw i lęków. Pani Jadwiga opowiada o takiej właśnie sytuacji, która przydarzyła się jej sąsiadowi: „Odczuł tą samotność mój sąsiad, co mieszkał naprzeciwko. Zadzwonił do mnie kiedyś rano i mówi: "Pani Jadwigo, potrzebuję pomocy». A ja pomyślałam, że może chce, żeby coś pożyczyć, albo coś kupić, coś przynieść, ja mówię: «Nie, to nie do mnie». A on mówi: «Wie pani co, ja bardzo źle się czuję i prosiłbym wezwać do mnie pogotowie»" (Jadwiga, 77 lat).

Osoby starsze mieszkające samotnie wskazują również na lęk umierania: „Ja boję się najbardziej tego, że na pewno będę umierała w samotności. I nie wiadomo, czy ktoś pomoże, chyba jak zaśmierdzi, to wtedy, na ten zapach ktoś wtargnie” (Jadwiga, 77 lat).

Inna jest sytuacja osób, które są zdrowe i mają możliwość wychodzenia z domu. Jednak i w takich przypadkach samotność niekiedy daje o sobie znać, choć są to inne jej oblicza. Pani Halina doświadcza jej w kontekście braku bliskiej relacji małżeńskiej czy partnerskiej: „Samotność [...] no nieraz ma człowiek takie chwile, szczególnie jak coś mu się nie powiedzie, jakaś przykrość go spotka. Raz ostatnio, jak coś przykrego mi ktoś powiedział, no to wtedy. A mam taki charakter, że nie umiem się bronić sama. Tak się trochę zastanawiałam, co by było, gdyby jeszcze mąż żył. No po prostu jak się ma męża, czy tam, jak dziewczyny w naszym wieku jakiegoś partnera, to zupełnie to życie wygląda inaczej. Bo nawet jak mnie dużo sukcesów różnych spotyka, wygrywam konkursy różne i tak dalej. Ten sukces jak odnosisz, to właściwie nie ma z kim go dzielić. Bo oczywiście jest córka, ale ona ma inny charakter, raczej powściągliwy. A ja mam taki wylewny. A ona: «No tak, no fajnie ci poszło», a wiesz, to tyle trudu kosztowało, a zupełnie inaczej to z mężem się dzieli sukces, czy dzieli jakąś porażkę, zupełnie inaczej jak jesteś w związku. Ja byle czym się zachwycam. A przyjaciele, no to dzwonią, pogratulują, no i co ci z tego? To nie jest to, dziewczyno, to nie jest to! Co prawda miałam na UTW propozycję wyjścia za mąż, ale mówię „Nie, nigdy w życiu, ja już nikogo nie chcę chować, niech teraz mnie chowają" (Halina, 85 lat).

Na znaczenie związku małżeńskiego - trwającej relacji dwojga osób - wskazuje wypowiedź pana Zygmunta: „No miałem zajęcie, no musiałem mieć, bo tu mnie nikt nie zastąpił. Te panie, co są, to są przez chwilę i odchodzą, ale nie narzekam, bo to mogło mnie się to zdarzyć, prawda? No to co? To była moja żona, tyle lat żyliśmy razem. To była nie tylko moja żona, ale i mój przyjaciel” (Zygmunt, 81 lat). Jego sytuacja wskazuje, że wcześniej miał możliwość przezwyciężania poczucia samotności, mimo że kontakt z jego zmarłą żoną z powodu jej choroby był bardzo utrudniony. 
Poczucie samotności pana Zygmunta ma inny wymiar niż samotność, o której doznawaniu opowiadają pozostali respondenci: „No są takie chwile, jak człowiek zaczyna przemyśleć cały bieg życia [...] tu było to, tu było to, teraz się to wszystko skończyło, wtedy dochodzę do tego, że miałem kiedyś bardzo dużo kolegów. Bo ja bardzo taki towarzyski byłem i jak człowiek zaczyna tak przemyśleć, to nieraz mam pretensje sam do Pana Boga, no, wszystkich mi pozabierał i ja sam zostałem. Chociaż to jest w przenośni to «sam», ale jak ja miałem wielu kolegów, w tej chwili ani jeden już nie żyje, to mi trochę przykro, ale rzadko. Zawsze mam zajęcia jakieś, to ja wtedy już nie myślę o tym" (Zygmunt, 81 lat).

Osoby badane przeżywają samotność w różnych chwilach swojego życia. Zdarza się, że otoczone innymi ludźmi czują się samotne subiektywnie, gdyż ich kontakty interpersonalne są rzadkie i powierzchowne bądź niesatysfakcjonujące z powodu różnicy pokoleniowej. Poczucie samotności pojawia się również w obliczu świadomości, że wiele osób z tego samego pokolenia już odeszło. Rozmówcy bardzo silnie odczuwają samotność mieszkaniową, która kojarzy im się z poczuciem uwięzienia oraz wywołuje strach przed ewentualnymi sytuacjami zagrożenia, $w$ tym również przed umieraniem w samotności. Rozmówcy próbują zwalczać negatywne emocje poprzez kontakty telefoniczne, chociaż nie czują pełnej satysfakcji z takiej formy kontaktu z drugim człowiekiem. Osoby żyjące samotnie przez dłuższy czas, potrafią przyzwyczaić się do tego stanu, mimo że odczuwają z jej powodu dyskomfort psychiczny. Badani wspominali także o samotności, którą odczuwają szczególnie dotkliwie w sytuacjach trudności życiowych bądź podczas odnoszenia sukcesów. Wskazują na potrzebę dzielenia się swoimi przeżyciami z drugim człowiekiem oraz na poczucie pustki po utracie najbliższej osoby.

\section{MOŻLIWOŚCI WSPARCIA SPOŁECZNEGO W NARRACJACH BADANYCH OSÓB}

Respondenci wiedzą o istnieniu instytucji adresowanych do osób starszych, które mają na celu wspomaganie ich w funkcjonowaniu społecznym, ale często korzystanie z ich oferty uniemożliwia im zły stan zdrowia. Dotyczy to przede wszystkim osób, które nie mogą samodzielnie wychodzić z domu. Na przykład choroba nóg pani Janiny uniemożliwiła jej uczęszczanie do takich instytucji: „O klubach seniorach słyszałam. Ale do takiego klubu ja nie mogłam pójść. Ze względu na moje chore nogi i na stan zdrowia córki nie mogłam uczestniczyć, bo byłam zależna od drugiej osoby" (Janina, 85 lat). Podobnie swoją sytuację przedstawia pani Zofia: „Kluby seniora, słyszałam, ale to nie dla mnie, bo mnie nie stać zapłacić tyle. A darmowe domy wiem, że są, ale ja z nich korzystać nie mogę, bo już nie chodzę sama i nie widzę" (Zofia, 85lat). 
Niektórzy respondenci korzystali z takich instytucji, lecz na skutek pogorszenia stanu zdrowia zaprzestali takiej aktywności. Pan Zygmunt wspomina swoją działalność w klubie zrzeszającym miłośników Lwowa i kresów południowo-wschodnich: „Kluby seniora - słyszeć słyszałem, nigdy nie byłem w takim [...], przez wiele lat należałem do klubu «Leopolis». Niedawno ten klub się rozleciał, tam już sami starzy ludzie byli i nie mogli przychodzić. Ja z niego zrezygnowałem cztery lata temu, jak mi żona zachorowała" (Zygmunt, 81 lat).

Podobna jest sytuacja pani Ewy: „Tutaj w mojej okolicy działa nawet klub seniora. Ja chodziłam na wykłady na UWT, bo to było to niedaleko. Ale potem zrezygnowałam, dlatego że byłam w szpitalu. Ale na początku to chodziłam. Nawet gdzieś legitymację miałam. A dzienne domy pomocy społecznej [...] słyszałam, ale ja się tym nie interesowałam" (Ewa, 85 lat). Dobrze poinformowani o ofercie różnych instytucji, skierowanej do seniorów są respondenci, którzy korzystają już z takiej formy aktywności społecznej i utrzymują stały kontakt z innymi osobami. Pani Halina stwierdza: „Oj, mnóstwo tego jest. Jest UTW, są kluby seniora, o tych dziennych domach też słyszałam, moja koleżanka tam chodzi” (Halina, 85 lat). Pani Jadwiga również wie o działalności takich instytucji: „O Uniwersytecie Trzeciego Wieku słyszałam, bo moja sąsiadka jedna z góry, jedna z dołu, chodzą. No to tam jest fajnie, bo są różni ludzie i nowe znajomości. Słyszałam o klubach seniora. I tam w tym klubie wydają legitymacje, albo kartę seniora i tam są różne zniżki, na różne towary, na przejazdy pociągiem, autobusem. Seniorzy, którzy są po osiemdziesiątce, to mają jeszcze dwa razy w miesiącu za darmo taksówkę. Wsiada, pokazuje tą kartę seniora i jedzie tam, gdzie potrzebuje" (Jadwiga, 77 lat).

Ciekawą ofertę dla osób starszych, którym stan zdrowia pozwala samodzielnie opuszczać mieszkanie przedstawiają dzienne domy pomocy społecznej. Z zajęć w takiej instytucji korzysta pani Jadwiga: „Tam dzień zaczyna się od rehabilitacji grupowej. Zbiera się nas 8-10 osób i z trenerką ćwiczymy. Później są zajęcia do wyboru, kto jakie chce. Prowadziłyśmy malarstwo, kucharstwo, muzyczne zajęcia. Przeważnie do trzeciej godziny są zajęcia. No i jeszcze mamy zajęcia na basenie" (Jadwiga, 77 lat).

Negatywne uczucia wzbudza w rozmówcach całodobowy dom pomocy społecznej. Badani instytucję tę porównują do szpitala: „Wydaje mi się, że tam będzie tak samo jak w szpitalu, że leżę, siedzę, chodzę trochę, jak mam z kim, bo przecież nie widzę, to sama nie mogę. To wydaje mi się, że tam będę jeszcze bardziej taka samotna. Nie wiem, jak oni to organizują, bo wiem, że oni tam dobierają ludzi, dwie, trzy w jednej sali, to jedna drugiej pomoże, choć to zależy na kogo się trafi. W naszym wieku co więcej nam zostało?” (Zofia, 85 lat). Podobnie dom pomocy społecznej wyobraża sobie pani Jadwiga: „Dobrą instytucją to jest taki dom pomocy 
społecznej dziennej. Dzienny, bo taki całodobowy, to mnie nie interesował, nawet nie wiem, jak tam jest, chyba tak, jak w szpitalu" (Jadwiga, 77 lat).

Wypowiedzi badanych potwierdzają koncepcję Elżbiety Dubas (2000, s. 118-124) dotyczącą wymiarów przekraczania samotności. Strategie wymienione przez respondentów można przyporządkować do następujących orientacji: ja - ja, ja - inni ludzie, ja - Bóg, ja - przyroda.

W ramach wymiaru budowania relacji ja - ja osoby badane pokonują uporczywe myśli o samotności, realizując swoje pasje lub znajdując sobie jakieś zajęcie. Tak robi między innymi pan Zygmunt: „Było, pomyślę, a potem przychodzi jakieś zajęcie. Biorę się za to zajęcie. [...] I już te myśli odchodzą. Nieraz robię coś na komputerze. Nieraz ktoś mi takie zlecenia daje, ja się trochę grafiką interesuję, jakieś zaproszenia, jakiś dyplom komuś dać, to robię" (Zygmunt, 81 lat). Ważne znaczenie zainteresowań i pasji w życiu osoby starszej dostrzega też pani Halina: „Trzeba się czymś zająć. Trzeba sobie jakąś pasję wyznaczyć. Musi coś sobie znaleźć, jak nawet nie ma jakiejś pasji, to czymś się zainteresować, dla siebie, tylko dla siebie" (Halina, 85 lat).

Dla innych respondentów sposobem pokonywania samotności jest czytanie książek. Poprzez czytelnictwo swoje zainteresowania rozwija pani Ewa: „Ja zawsze potrafiłam sobie znaleźć jakieś zajęcie. Przede wszystkim dużo czytam. Czytałam zawsze, nawet jak chodziłam do szkoły, to zaczytywałam się. Zawsze jak nie miałam co do roboty, to się chwytałam pierwszą lepszą książkę i czytałam. Bardzo lubię książki historyczne, interesuje mnie też teatr, malarstwo, kino, muzyka. Jak przyjechałyśmy z mamą ze Lwowa, to przywiozłyśmy kufer pełen książek” (Ewa, 85 lat).

Kolejną osobą, która wolny czas spędza w samotności, czytając książki jest pani Jadwiga: „Ostatnio to książki mnie wzruszały. Czytałam, ile się dało, tyle czytałam. Ostatnio przeczytałam pięć kryminałów. Dostałam od «Szlachetnej Paczki» w prezencie" (Jadwiga, 77 lat).

Utrudnioną sytuację mają osoby, które są słabowidzące. Tego problemu doświadcza pani Zofia: „Siedzę, leżę, słucham radia. Jeszcze jak widziałam, to czytałam, krzyżówki mogłam rozwiązywać. Teraz tego nie mogę robić, ale kiedyś lubiłam szyć. Lubię bardzo sprzątać, tylko nie widzę" (Zofia, 85 lat).

Kolejną strategią pokonywania samotności przez osoby w wieku późnej starości jest budowanie relacji ja - inni ludzie. Pani Barbara wspomina swoją wspólnotę sąsiedzką: „Jak mieszkałam sama, to z sąsiadami, nas szesnaście lokatorów tam było, bardzo fajnie, w zgodzie żyli, sąsiadów miałam [...], ja od czterdziestego szóstego roku tam mieszkałam. Bardzo fajnie się mieszkało, nigdy nie było kłótni, nie było jakichś tam nieporozumień” (Barbara, 83 lata). Również duże znaczenie dla pani Zofia ma relacja z sąsiadami: „Nieraz zejdę do półpiętra, to zaraz Marysia mnie woła z powrotem, bo boi się, że się przewrócę. Ja wiem, że takie domy dziennej 
pomocy są, nawet tu blisko nas, Marysia mi powiedziała. Ja zawsze jej pytam, co tam nowego i ona mi opowiada" (Zofia, 85 lat).

Za niepokojące można uznać, że rozmówcy odczuwają brak kontaktu z młodymi sąsiadami. Tak życie sąsiedzkie wspomina pani Janina: „Ważne jest też dobre sąsiedztwo. Kiedy moi sąsiedzi żyli, to nie odczuwaliśmy tego. Ale wiek zabiera każdego po kolei. Zostali młodzi, a ci są zajęci sobą" (Janina, 85 lat). Dla rozmówczyni skuteczną strategią radzenia sobie $\mathrm{z}$ poczuciem osamotnienia jest budowanie relacji ja - Bóg i życie religijne: „Kościół. Wiara jest fundamentem człowieka. Można w życiu wszystko stracić, ale nie wiarę. Wiara katolicka jest trudna, ciężko to zrozumieć czasami. Ale nie potrzeba tyle tego wszystkiego czytać, żeby wierzyć” (Janina, 85 lat).

Pani Halina opowiada o swojej kuzynce, która również przezwyciężała poczucie samotności poprzez relację ja - Bóg: „A z kolei moja kuzynka, zmarła w zeszłym roku, ona swoją samotność utopiła w kościele. Ja ją podziwiałam, wszystkie święta [...], ja też jestem katoliczką, wierzącą, ale nie tak jak ona, wszystkie święta, modlitwy, ona wszystko wiedziała! Kościół jej dawał siłę, ta mocna wiara dawała jej sił” (Halina, 85 lat).

Strategia relacji ja - Bóg stanowi pewne remedium na poczucie samotności i wspiera osoby wierzące nie tylko w przekraczaniu samotności, ale również w poszukiwaniu sensu życia. Jednakże odnosi skutek wyłącznie wtedy, kiedy wynika z pełnego przekonania i wpisuje się w potrzeby osób starszych. Natomiast bez osobistego zaangażowania może narastać jedynie poczucie bezcelowości podejmowanych działań. Taka jest właśnie sytuacja pani Barbary: „Wożą mnie codziennie do kaplicy, no może grzeszę, ale nieraz to się nie chce iść. Tylko się modlić, i modlić. To różaniec, koronka, i tak cały czas, teraz jeszcze majowe, to znów. I tak cały dzień zajęty"(Barbara, 83 lata). Dla autorki powyższej wypowiedzi uczestnictwo w praktykach religijnych jest stratą czasu, który wolałaby wykorzystać na rozmowy telefoniczne. Poczucie przymusu prawdopodobnie budzi w niej opór i zniechęca do praktyk religijnych, utrudniając jej tym samym odczuwanie satysfakcji z nawiązywania relacji ja - Bóg.

Ciekawą strategią pokonywania poczucia samotności jest budowanie relacji ja - przyroda. Tę strategię stosuje pani Ewa, która odnajduje poczucie równowagi wewnętrznej, obserwując naturę i otaczając się zwierzętami: „Jak mogłam chodzić, to szłam na spacer i lubiłam obserwować przyrodę, świat, zwierzęta. Czuję się zdrowsza, jak są przy mnie koty. Dzięki kotom ja się czuję zdrowsza! Poza tym rozmawiam sobie ze zwierzęciem, które patrzy na mnie i wydaje się, że rozumie wszystko. A poza tym dom bez zwierzęcia jest pusty. Pamiętam, gdy byłam w szpitalu dwa tygodnie i jak ja wróciłam, to sąsiadka do mnie mówi tak: «Pani Ewa, czy pani sobie wyobraża, że kotka płakała? Normalnie płakała». A więc człowiek i zwierzę przyzwyczajają się do siebie!” (Ewa, 85 lat). 
W zwalczaniu samotności osoby badane przyjmują cztery strategie budowania relacji: ja - ja, ja - inni ludzie, ja - Bóg i ja - przyroda. W obrębie pierwszej z nich rozwijają swoje zainteresowania oraz szukają sobie zajęć odwracających uwagę od poczucia samotności. W ramach relacji ja- inni ludzie rozmówcy starają się pielęgnować swoje kontakty z sąsiadami. Relacje sąsiedzkie stanowią szczególne wsparcie dla osób mieszkających samotnie, czego dowodzą również badania na temat osamotnienia osób starszych w Polsce prowadzone przez Piotra Kubickiego i Martę Olcoń-Kubicką (2010, s. 131-137). Każda z przedstawionych strategii może wpisać się w potrzeby i możliwości osób starszych, a jednocześnie stanowić remedium na poczucie samotności i osamotnienia.

\section{KONKLUZJA}

Podsumowując, charakterystyczne dla większości wywiadów jest łączenie przeszłości z teraźniejszą, tęsknota za najbliższą rodziną, potrzeba kontaktów społecznych, tęsknota za swoją młodością, aktywnością, brak perspektyw na zmianę swojej sytuacji. Badani odczuwają też potrzebę kontaktów społecznych, szacunku, wzmocnienia ich poczucia godności i użyteczności.

Na życie codzienne człowieka dorosłego składają się aktywności w różnych jego obszarach: rodzinie, pracy, środowisku lokalnym. Bardzo istotną determinantą codzienności jest przestrzeń życiowa, którą najczęściej tworzy dom rodzinny. Kolejnym ważnym wyróżnikiem są relacje społeczne. Oprócz tego, że zmieniają się warunki życiowe, to przede wszystkim dochodzi do przemiany relacji z rodziną. Pojawia się także zależność od obcych osób. Analizując kwestię samotności i poczucia osamotnienia badanych osób, nasuwają się następujące wnioski:

1. Znamienne jest, że wszyscy badani deklarują poczucie osamotnienia i wskazują na przykry stan psychiczny, o różnym nasileniu, który z tym się łączy.

2. Poczucie samotności i osamotnienia jest wieloaspektowe, ale w przeprowadzonych badaniach zaznaczyły się dwie grupy istotnych czynników w doświadczaniu tego stanu. Pierwsze odnoszą się do wdowieństwa, braku bliskich relacji z rodziną, znajomymi. Natomiast drugie związane są ze stanem zdrowia.

3. Najważniejszym czynnikiem codzienności, którego oczekują badane osoby, są kontakty interpersonalne z rodziną. Osobom starszym, schorowanym nie wystarczy dobra opieka, ale potrzebne jest zrozumienie i kontakt $\mathrm{z}$ drugim człowiekiem.

4. Realnym zagrożeniem dla osób w wieku późnej starości przeżywających samotność i osamotnienie są zaburzenia o charakterze depresyjnym. 
5. Badane osoby znają instytucje wspomagające ich aktywność czy relacje społeczne, ale symptomatycznym jest to, że nie wskazują na instytucje pomocowe, do których mogliby zgłosić swój problem wynikający z poczucia osamotnienia.

6. Ochrona osób w wieku późnej starości przed poczuciem samotności i osamotnienia jest bardzo ważnym aspektem, który powinien zostać dostrzeżony w polityce społecznej państwa.

7. Spośród wielu czynników chroniących osoby starsze przed poczuciem samotności i osamotnienia nie należy pomijać stworzenia dobrych warunków socjalno-bytowych, które powinny zapewnić godne życie, z dostępem do opieki medycznej i wpisujących się w inne potrzeby tych ludzi.

8. Czynnikiem chroniącym przed poczuciem samotności i osamotnienia jest umożliwianie osobom starszym różnego rodzaju kontaktów społecznych. Na szczególną uwagę zasługują rozwiązania w kierunku relacji międzypokoleniowych.

Reasumując, konieczne wydają się działania zmierzające do usprawniania i poszerzania opieki nad osobami w wieku późnej starości. W planowaniu tej opieki należy brać pod uwagę ich sytuację socjalną, warunki mieszkaniowe, ekonomiczne oraz możliwości wsparcia. U schyłku życia osoba starsza, która pracowała, wychowała dzieci, przyczyniła się do rozwoju swojego społeczeństwa, w swoim życiu codziennym oczekuje traktowania z godnością. W tym okresie życia bardzo ważne jest wsparcie i pomoc, ale jeszcze bardziej zrozumienie, uważność, umiejętność słuchania i szacunek.

\section{LITERATURA}

Christiansen J., Larsen B.F, Lasgaard M., 2016, Do stress, health behavior, and sleep mediate the association between loneliness and adverse health conditions among older people? „Social Science Medicine”, 152, 80-86.

Demetrio D., 2000, Autobiografia. Terapeutyczny wymiar pisania o sobie. Kraków, Oficyna Wydawnicza „Impuls”.

Drageset J., Eide G., Furnes B. i in., 2015, Loneliness, loss, and social support among cognitively intact older people with cancer, living in nursing homes - amixed-methods study. „Clinical Interventions in Aging”, 10, 1529-1536.

Dubas E., 2000, Edukacja dorosłych w sytuacji samotności i osamotnienia. Łódź, Wydawnictwo Uniwersytetu Łódzkiego.

Heitzman J., 2018, Psychiatria w geriatrii. Poznań, Wydawnictwo Termedia.

Kos E., 2013, Wywiad narracyjny jako metoda badań empirycznych. W: D. UrbaniakZając, E. Kos (red.), Badania jakościowe w pedagogice. Warszawa, PWN, 91-119. 
Kubicki P., Olcoń-Kubicka M., 2010,Osamotnienie osób starszych w Polsce - skala, przejawy oraz sposoby przeciwdziałania zjawisku. „Studia Humanistyczne AGH”, t. $8,129-138$.

Pilch T., Bauman T., 2010, Zasady badań pedagogicznych. Strategie ilościowe i jakościowe. Warszawa, Wydawnictwo Akademickie „Żak”.

Posłuszna M., 2012, Aktywność rodzinna i społeczna osób starszych. „Nowiny Lekarskie", t. 81, nr 1, 75-79.

Stochmiałek J., 2012, Kryzysy starości- wybrane uwarunkowania. W: A. Zych (red.), Poznać, zrozumieć i zaakceptować starość. Łask, Wydawnictwo Progress, 85-108. Szczupał B., 2018, Dignity, everyday life, support for seniors with disabilities. „Interdyscyplinarne Konteksty Pedagogiki Specjalnej”, nr 24, 15-26.

Szukalski P., 2005, Poczucie samotności i osamotnienia wśród sędziwych seniorów, a ich sytuacja rodzinna. „Auxilium Sociale - Wsparcie Społeczne”, nr 2, 217-238.

Świtoń A., Wnuk A., 2015, Samotność w obliczu niesprawności osób starszych. „Geriatria", nr 9, 243-249.

Wiśniewska J.I., 2018, Educational activity of seniors as a predictor of successful ageing. „Interdyscyplinarne Konteksty Pedagogiki Specjalnej”, nr 24, 27-46.

Ziomek-Michalak K., 2015, Znaczenie rodziny w starzeniu się i w starości człowieka. „Roczniki Teologiczne”, z. 5, 175-194.

\title{
LONELINESS AND A SENSE OF LONELINESS IN THE NARRATIVE OF PEOPLE IN OLD
} AGE - MANIFESTATIONS AND OPTIONS FOR COUNTERACTING

\begin{abstract}
The process of ageing is an inevitable life phenomenon in both the individual and social aspects. The elderly are vulnerable to the appearance of a sense of isolation and loneliness. Loneliness is identified with the deficiency of relationships or significantly reduce them. Loneliness almost always leads to marginalization or exclusion of older people who experience it. The article presents the results of qualitative research on loneliness and a sense of loneliness in the narrative of people in old age.
\end{abstract}

Keywords: loneliness, elderly person, people in old age, social support 